\title{
The Twentieth Century Crusades, and What They Taught One Member of the Five Hundred
}

\section{Estelle Appleton}

To cite this article: L. Estelle Appleton (1909) The Twentieth Century Crusades, and What They Taught One Member of the Five Hundred, The Pedagogical Seminary, 16:1, 23-48, DOI: 10.1080/08919402.1909.10532567

To link to this article: http://dx.doi.org/10.1080/08919402.1909.10532567

册 Published online: 30 Aug 2012.

Submit your article to this journal $₫$

Џ Article views: 3 


\section{THE TWENTIETH CEN'TURY CRUSADES, AND WHAT THEY TAUGHT ONE MEMBER OF THE FIVE HUNDRED}

By L. Estel, APPLEToN, Fellow in Psychology, Clark University

Significance. No more striking illustration of the rapidly changing attitude toward both the method and content of Educational Training can be found, than in the pedagogicsociologic-economic movement which has recently impelled upwards of one thousand teachers to cross the ocean on organized tours of scholastic investigation. Furthermore, these Twentieth Century Crusades by their characteristic features, not only indicate fairly well the distance travelled in the evolution of civilization since the close of those earlier Crusades of mediæval fame, but, by the same tokens, they point out schematically the tendencies in the Educational Method of the Future. Investigation, not dogma; construction, not destruction; co-operation, not domination; internationality as distinguished from nationality of type; universality of scope; reciprocity of benefits; recognition of the fallibility of tradition; conformity to changing conditions;-all these are characteristics either not thought of at all, or deemed heretical, at this earlier period, but which, nevertheless, are sure to be more and more accentuated in the activities and philosophies of the World's Tomorrow.

It is extremely significant that the champion of this Dynamic Pedagogy, - this Educational Crusade, - is not himself an educator in the ordinary acceptation of the word, but one whose interests lie rather in industrial lines, thus indicating that as Education is no longer the perquisite of theology and the professions, but now extends also to the working classes, so no longer can Instruction afford to ignore the suggestions and needs of the Industries in shaping its future policy. Indeed not a little of the interest attaching to this whole movement is due to the manner of its development from the "Mosely Industrial Commission to the United States" in 1902, and the "Educational Commission"' in 1903 .

Origin. Mr. Alfred Mosely, of London, writes in his Report of 1903:

"The origin of the Industrial and Educational Commissions to the United States takes me back to South Africa some fifteen years ago. I had for many years been engaged in mining operations at Kimberly, 
which, in common with the work of the great bulk of the diamond diggers, had proved unremunerative, when Gardner Williams, the Californian engineer, arrived in South Africa, and took over the management of the DeBeers Company, which the late Cecil Rhodes was just then amalgamating. Gardner Williams in turn imported the late Louis Seymour. . . Uader the guidance of these able men and many others, the development of South Africa was started; and in my opinion, her mining centres owe their pimary success and subsequent prosperity to their efforts. . . The success of these engiueers turned my attention to the United States, and some years ago I paid my first visit there for the purpose of seeing what sort of country it was that was responsible for sending so many level-headed men to the Cape. I spent some months in the country and was astounded at what I saw around me, not so much at the state of development that had been reached at that time as to what I discerned of the future. I felt that a country teeming with such natural resources must, in the hands of capable men thoroughly acquainted with their business, play an important part in the future of the world, and was bound to exercise a far from negligible influence upon the industries of the United Kingdom. So far as I was able to ascertain, the form of Education given in the United States is responsible for much of its success, and I returned home determined if possible, to get together a party of experts to visit the country and test the soundness of my conclusions. . . Holding these opinions, I orgauized my two commissions, the work of which is now too well known to require any long description from myself." . .

The reports of these Commissions were published, read and discussed in England, and from the familiarity which the English teachers seemed to have of their contents, we venture to think they may have had some effect in shaping the more aggressive educational policy which came in with the passage of the Parliamentary Education Act of 1902.

Following up, approximately, the methods and purposes of these two Commissions, and being aided by the most generous co-operation of $\mathrm{Mr}$. J. Bruce Ismay, President of the International Mercantile Marine Company, Liverpool, and by the National Civic Federation on this side the water, Mr. Mosely organized, in 1906 , a still larger body of about three hundred English teachers and school officials, to investigate the methods and equipment of the schools of the United States, and, during the year just passed, five hundred American teachers were invited to visit English schools. It was the writer's good fortune to be one of the American Five Hundred.

We say "good fortune," for surely no person travelling under ordinary circumstances could possibly receive such an abandon of helpful service as our hosts lavished upon us, or could possibly gain in so short a time, so much insight into educational and social conditions. Looking back now upon the visit to England, one of the chief sources of pleasure connected with the tour, is the memory that so many persons, representing so many classes and conditions of life, contributed 
in such various ways to the pleasure and success of the whole undertaking. On my table now are invitations to twentythree receptions given during the eight weeks' residence in London, not including many informal receptions given by associations of various kinds, nor many private lunches, dinners, and afternoon teas proffered by individuals. These courtesies were offered not only by persons immediately connected with the schools, but by many outside the pedagogical ranks, for example Mr. Mosely himself, who welcomed the strangers to his delightful suburban home, and our own American Ambassador, Whitelaw Reid. As many of these receptions were held week after week during the whole period of the crusade, as different detachments arrived, - that is from September to January or perhaps even later, it will be seen that the expenditure was very great, not merely of money, but of valuable time and of patience with guests unacquainted with each other and unfamiliar with English customs.

Other persons conducted groups of teachers about the city or arranged excursions beyond the city, usually at reduced rates. Southampton, with a large part of its mediæval wall still standing; Winchester and Salisbury cathedrals, one with its noble external proportions, the other with its beantiful interior; Stonehenge, sacred to the memory of a past mythology; Stoke Poges, the birthplace of Gray's "Elegy;" the ancient "Burnham Beeches" from which one of our party triumphantly brought home a horsechestnut as a souvenir; Eton College, where, since 1440 , the aristocracy of England has largely received its education; beautiful Windsor Castle, one of the nost magnificent of royal residences; stately Hampton Court Palace, Cardinal Wolsey's princely gift to Henry VIII; Oxford University; Edinburg, Paris - all contributed their share to the pleasure and profit of our journey.

London. Loudon, too, had its strong attractions. Westminster Abbey, which no traveller passes by; St. Paul's Cathedral, where Reformation strifes raged furiously, "where heretics were made to recant and witches to confess," where Wycliffe was proclaimed an outcast from the church, Luther condemned, and Tyndale's Testament burned; the City Temple, in which London's 'Socialist Preacher,' Rev. R. 'T. Campbell, now dispenses heterodoxy to Churchmen and sympathy and comfort to crowds of worshippers whom formalism does not satisfy; the Tower of London, with its precious treasure of Crown Jewels, and its suggestions of awful tragedy; the Guildhall, so closely associated with the political life of England; "Madam Tussaud's," where much of the world's history is epitomized in wax; Buckingham Palace; the Franco-British Exhibition;each deserves a chapter which cannot be given here. 
Nor could the social and political phases of English life entirely escape attention in a city in which street processions, made up from the rank and file of the "millions of unemployed," bear witness to the terrible stress and strain of modern civilization where the poorer classes are concerned, the submerged tenth, which, like the deep-sea life, never gets a chance to come to the surface for a full, life-giving breath.

So also did the vagaries and disorders of the Suffragettes furnish equally pointed testimony to the fact that the struggle for political liberty is not yet entirely fought out.

For the first of these great problems now claiming the attention of Parliament, the solution seems almost hopeless in a land where class distinctions are firmly drawn and where much of the old guild spirit of monopoly still lives. The second is likely to 'work out its own salvation' in the not far distant future, if the present Governmental policy continues, inasmuch as the only apparent result of imprisoning the leaders of the movement is to add hundreds of enthusiastic adherents to the party. In a nation which, during one and a quarter centuries of its history, has acknowledged the power, ability and right of women to rule over the property, lives and destiny of the whole English people, the spectacle of the government throwing into prison a few helpless women whose greatest crime is that, having experienced the futility of peaceable appeals, they now propose a clamor sufficient to cause 'the ears of the deaf to be unstopped' while they present their claims for equal opportunities with men in ruling over their own individual interests, - such a spectacle presents elements, at least, of inconsistency. The Suffragettes are undoubtedly making headway, however, and some of those who have suffered most by imprisonment, are confidently expecting the franchise by the end of another two years.

These interesting investigations were, to be sure, incidental to the main purpose of the journey, which was to study educational institutions, and yet, perhaps just these experiences furuished, after all, the best part of the educational value of the whole excursion; for, as never before, the breath of life breathes into the dead facts of European History and its dry bones clothe anew with living flesh and pulsing blood as we are looking at the evidences of the old fierce struggle for political equality; bowing again before the ancient altars where heretics recant; listening to the groans of tortured unbelievers; standing within the old walled towns of Feudal Days; seeing once more the emblems of Chivalry; hearing anew the clank of armor and clash of swords of those other crusaders.

What wonder that with such scenes to inspire, each valiant knight should be seized with holy zeal to beat down the 
bulwarks of ignorance and pride! Our army soon opened a fire of questions upon the enemies rauks. "Do you mean tons of water or tous of coal?" asked one of the besiegers, of a ship's officer patiently explaining the meaning of the "ship's displacement" of a certain number of tons. "I rather think they'll weigh about the same, mum," was the polite answer.

Another member of the party in a loud and most troubled tone of voice said to a train official standing by her car window, "Now, I want to meet a man; if I take this train shall I meet him?"' "I can't say about that, mum,' was the still courteous reply, "if you keep going, and he turns up, you'll meet."

In vain to suggest to Don Femina Quixote, who, charging upon the "Famous Burnham Beeches," brought back the sacred relic already alluded to, that 'horse chestnuts do not often grow on beeches!' One withering glance of scorn transfixed the Infidel, while righteous indignation punctuated and emphasized each word of her reply! "Miss A-!!' I-picked-that-up-rightunder-the-trees!!!"

Special Features of English Schools. Most of our conquests, however, were of a more prosaic ty pe, and the remainder of this article will be concerned with educational investigation of the type to which the term is usually restricted. Arriving in London we proceeded to the offices of Mr. Mosely and of Mr. Blair of the education department of the London County Council. Both of these gentlemen, together with Mr. Gautrey, secretary of the London 'Teachers' Association, his assistant, Mr. Pincombe, and many others, rendered the visiting teachers invaluable service, advising and aiding in every possible way, and putting each one immediately in touch with the work in which that one was individually interested.

Through the kindness of the administrative officials of the School of Economics and of Professor L. T. Hobhouse and Doctor Alfred Haddon of London University, the writer was permitted not only to visit as many university classes as she desired during her brief sojurn in London, but also to enter the classes of the last named gentlemen as a regular student, thus enabling her to get an inside view of an English University. This much prized opportunity necessarily limited the time devoted to the study of the educational system as a whole, making it desirable to focus observation and energies upon the nore unfamiliar aspects of school life. Among these special types a word concerning the University itself may not be out of place.

The University of London. The University of London came into existence chiefly in response to the demands of NonConformists who had been excluded from the older universities. Previous to 1900 the work of the University was limited to the examination for degrees. "In 1878 , the Senate and Convoca- 
tion agreed to accept from the Crown a supplementary charter, making every degree, honor and prize awarded by the University accessible to students of both sexes on equal terms. The University of London was thus the first academic body in Great Britain to admit women as candidates for degrees." Furthermore, this equality of sexes in opportunity is apparently actual, not merely a pretense as in some departments of our American colleges, where, though theoretically the sexes are on equal terms, practically most of the opportunities, aside from lectures, are really reserved for men.

There are now twenty-seven schools affiliated with the University. Sixteen others offer certain courses which are regarded as University work. University extension is an important feature, one hundred ninety courses having been held during the past year in sixty different centres in and about London.

Regarding the character of the work done as compared with that offered in America, our observations were too brief to be of much value. We have already intimated that our own short experience as a pupil was of the happiest sort. Nor did we find that stiffness and cold formality which we are accustomed to attribute to English schools. The lectures in most of the classes visited were characterized by an interchange of thought between pupils and teacher, which we are inclined to regard as exclusively an American characteristic. On the other hand we saw none of the students of middle age and advanced years who form so prominent a feature of our own academic bodies, and it seemed as if the students were less thrown upon their own resources in reaching conclusions than in America; that they did less supplementary reading in connection with their various studies; that there was less laboratory work required; that what was required had less of the type of original discovery; and that so far as one might judge by mere numbers of pupils enrolled in various classes, that young men and women in London do not seem to show the same interest, in philosophical subjects, at least, as those of the United States. For example, in three classes in Psychology which I visited, the numbers varied from three in one class to five in the second, and twenty-four in the third. In classes of similar rank and corresponding subject matter which I had attended in Chicago University, the numbers varied from about fourteen to fifty. In ethics we found about twenty in both London and Chicago Universities; in Anthropology six in London, about sixty in Chicago; in Histology of the Nervous System one pupil in London, in Chicago seventy. These numbers may have been more than counterbalanced in other departments; however, I find the number of studeuts on the University roll given as 
5,613 , and the whole number of teachers as 826 , giving an average of six or seven pupils to a teacher. After sitting for two hours in succession in King College, on the most uncomfortable benches it was ever our misfortune to find in a schoolroom. this disproportion between the two Universities was not surprising.

The number of teachers in the different Faculties makes a very good index of the relative strength of different departments of the University. According to statistics furnished at the Franco-British Ex hibition, medicine has the largest faculty, numbering 397. The others stand as follows: Science, I53; Arts, I I 5; Engineering, 48; Economics, 34; Theology, 26; Law, I6: Music, r4. The classes mentioned in the preceding paragraph are included in Science and in the School of Economics.

One interesting phase of the work of the University of London is the Department of "Eugenics" with its laboratory for research endowed by Mr. Francis Galton. Eugenics is defined as "the study of agencies under social control that may improve or impair the racial qualities of future geverations, either physically or mentally." The object of the study is thus stated by Mr. Galton:

"The fact that the laws of heredity apply to man equally with the lower animals and plants, and that the mental functions are subject to the same laws of heredity as the physical ones, has yet to be taken to heart by the public. The salutary effects of natural selection in preventing the degeneracy of the race are so largely interfered with, and sometimes even inverted, by civilization, that another form of prevention is peremptorily demanded." "The power of public opinion being enormously great, we may rest assured that after the impo: tance of Eugenics shall have become generally recognized, many social influences will be brought to bear, and numerous customs will establish themselves that shall further Eugenic conduct with a gentle yet almost irresistible force."

Another interesting phase of research work being carried ou by the University of London is the study of Tropical Diseases, especially in the Colonial Possessions of the British Empire. In the University's exhibit at the Franco-British Exhibition, was a small but interesting collection of primitive surgical instruments, such as shell and bamboo lancets, snares for extracting ingrowing lashes, medicine cups of cocoanut shells, poisoned arrows, etc, Pictures of persons afflicted with elephantiasis, sleeping sickness, bite of tzetze fly, and other peculiar forms of sickness were exhibited, also a picture of a health officer of $720 \mathrm{~A}$. D. wearing a mask representing a bird's head as a protection against the Plague.

Medical Inspection of Schools. After the University, perhaps the schools for delicate children and those physically and mentally defective were most interesting and suggestive. 
The English people are certainly in advance of us in the matter of keeping a systematic lookout upon the physical condition of children entering school. "In 1906 and 1907 respectively, legislative power was given to local authorities for the feeding of necessitous school children in England and Wales, while medical inspection of all children attending elementary schools was made compulsory." A child who is physically crippled or is mentally unable to keep up with his classmates is sent to a "Cripple School" where seats and desks and work are especially adapted to their individual needs and where school work also can be varied as occasion demands. Basketry, embroidery, and other fancy work, and hand work of various kinds make up a large part of the curricula of these schools. Art work has a large place. The excellent results obtained in the Montpelier House school for the physically deficient, or P. D.'s, would have been creditable for normal pupils. Incidentally, many a little lesson of politeness and thoughtfulness is learned in the practical way of helping some weaker child to get his crutches, or perhaps his seat at the table. All are fed at the school. Each child pays a penny (two cents) a day and this sum is sufficient to cover the actual cost of the food. 2,250 "P. D." children are now attending 28 of these special schools in London. Three or four of the schools are in hospitals, where the children receive care outside of school hours as well as during study time. Many of the children occupy their invalid chairs while working or studying.

"M. D. Schools." About 7,000 mentally deficient children, in London, in 84 special schools, are similarly segregated, not including children whose mental deficiency is so great that they are not capable of benefiting by instruction. Midday meals are provided for them by voluntary contributions. Every child under these two classes and the next to be mentioned is under continuous medical inspection. Where the need is greatest, a nurse is added to the teaching staff. A record is kept of each child, a history of the parents and a record of the improvement or lack of improvement.

These medical examinations go on every school day in the week except Thursday. The mother or some near relative is required to come with the child. On the day of our attendance twenty-one children appeared before the physician. In nearly every case there was a record of delicate bealth. One child had enlarged tonsils, one weak lungs and glandular enlargement, one a paralyzed hand. One had "'ad a lot of falls on 'is 'ead ;" two had Bright's disease; one was somewhat deformed; two were hydrocephalic; two children presented indications of eye trouble; five had fits; one much emaciated little fellow exhibited a bad case of hemophilia ; two girls had faint- 
ing fits. Most of the children were under size, one or two over grown. Several had already been under bospital treatment.

The mothers were quite as interesting a study as the children, giving us, as they did, many a little glimpse of home conditions of the poorer classes of London. One mother spoke bitterly of the hardship of having to send her sickly epileptic daughter to school when her ailments were incurable, and she was likely to have fits at any time and complained that she could not fully explain the child's absence from school to the teacher since she "was n't allowed to speak up to the dominie"; but most of the mothers came with a silent reserve and apathetic patience which spoke volumes concerning the "struggle for life". One mother could neither read nor write; one could read a very little but said her husband was "very dull." One mother was a paralytic and a daughter came in her stead. Another mother had eleven children living and three were dead. When asked the age of the one with her, some rather detailed mathematical computations were apparently executed before she was able to answer "Seven." One mother reported ten children, another "Seven, the oldest not yet fourteen." Her husband had been out of work for six months. When asked, "How do you live if your husband is out of work?" the answer was, "I earns a shilling a day when I can, mum." Still another came to answer for her little dwarfed, pale-faced, squinteyed, eight-year-old boy who "'ad 'ad Bright's disease and dropsy and could not keep up with his classes." In her arms was a frail bit of a baby girl with white, pinched, expressionless face the blue veins straggling over temples and mouth. The mother spoke no word of complaint but when questioned about the food the children were getting said, "No, we don't 'ave milk. My 'usband can't get work. Of course we can't 'ave the proper food for the childern."'

One fact which the examination brought out was that of the whole number examined, sixteen were boys, only five girls. We were told that this disproportion was usual, nothwithstanding the fact that more girls are born than boys. [Referring for comparison to the last report of the superintendent of New York City Schools we find that in every table of statistics given relating to defective children the number of boys is more than twice as great as the number of girls.]

In disposing of the backward children, a few were told to continue in their classes for the present-a few were taken out of school; some were transferred to classes for mentally defective; and some were sent to the hospital for treatment. Two or three were put on the list of "necessitous children" and the mother of the squint-eyed boy and sickly baby was told that she should be given milk for the children. 
No wonder that these twenty-one children, who were only a haphazard sample of the procession continually pouring into the superintendent's office, were 'behind their work in school'! And how much better it would be in our own schools, if instead of scolding and punishing those who do not get along well, or simply putting them back, we should make a similar careful and methodical investigation of the reasons why they are failing and a similar methodical attempt to better the conditions. When we have ferreted out the causes of such mental disability we shall also have discovered the means of preventing the "physical deterioration of the race." Nowhere is there such an opportunity to get at the facts as through the medium of the public school, or rather, this would be the case, were our compulsory attendance laws enforced. ${ }^{1}$

Appropos of the subject of physical degeneration, we may bere refer to a study of Miss Alice Ravenhill as presented in a meeting of the Child Study Association, London, concerning the sleep hours of school children, and the conditions obtaining meanwhile. She found that English children of ten years old are getting about one hour less sleep per day than they should have, and that the curve of sleep dropped still lower as the errand boy age was reached. Some children only six years old rose at five o'clock in the morning to assist in work of various kinds. "At six years old $2 \%$, at 9 years $13 \%$, at i 2 years $53 \%$, at 13 years 5 I $\%$ are wage earners." . . "Two little boys of five are sent on village milk rounds daily at 5.30 and 6 A. M. respectively . . . a boy of ten rises three days in the week at 3 A. M. for market, while one of eight and two of nine get up at 4 A.M. for the same purpose." . . " One child is a member of a family of eight living in one room . . ." "The worst case of overcrowding recorded is that of a lad of thirteen, the youngest of the nine, to whom this one room represents home."

Another speaker of the evening considered the effect of loss of sleep upon physical development, and claimed that at six or seven years there is a difference of two inches in height between those getting curtailed hours of sleep and those getting a sufficient amount; furthermore that this difference increases with years.

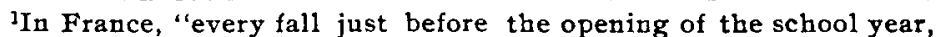
the mayor of the commune sends to the principals of all public and private schools a list of all the pupils that ought to be at the various schools. In accordance with this information the principals send to the mayor of the commune and to the school inspector a list of all abseuces for the month with the causes thereof. The mayor, as president of the local school commission is then responsible for instituting proceedings against the parents of children that are not at school." Preliminary Report of N. E. A., 1908, p. 33 .
} 
We may say to ourselves these conditions do not obtain anong us, but we do not know whether they do or not until an investigation has been made. It is said that in Chicago a child of foreign parentage was sent home with the request that she be given a bath. An angry reply came back from the mother to the effect that 'she had sewed that child's clothes on to stay and she did n't want them ripped off!'

From the Ninth Annual Report of the City Superintendent of Schools of New York, 1907, we quote the following from that portion which deals with "Defective Children:"

"An undersized, nervous, elf-like girl of nine years, she could keep awake and alert except when required to sit at her desk. The moment she was still, her head was down and school forgotten; sleep would overpower her. Here was, indeed, a strange condition-a child apparently well, sleeping early in the school day. A word or two brought out the fact that this child, a mere baby, was required to rise at five o'clock in the morning, to sew buttons on boys' trousers until school time; after school in the afternoon she was again compelled to take up the burden and work far into the night. This child $\mathrm{knew}$ that two different sizes of buttons were used, knew where to place them; she knew that ten buttons were put on one pair of trousers, and twenty on two, but beyond that she could not go. . . The child had ability but it was used up each day before the school received her. The fact of sleeping, in this particular case, was due to fatigue. Nature was doing ber work; school had to wait. . . It was found upon investigation that the father was saving his earnings; while his wife and this child were providing food and shelter for him and one younger child,"

Such conditions as this in our own land are suggestive, at least, of all other hygienic and social evils. Only a few days ago we saw four little boys, apparently about eleven years old, selling newspapers at five o'clock in the cold, wet winter morning. Would it be surprising if these tired children should be reported before night by their teachers as giving trouble in 'discipline', or at the end of the year as "not up with classes"?

Open Air Schools. The third class of schools for backward children is the Open Air School. These are desigued, not for the physically disabled, nor for the mentally incompetent, but for those children whose delicate health makes it unwise or impossible for them to be urged forward at the same rate and under the same conditions as strong and healthy children. They are in most cases suffering from anæmia, incipient consumption, eularged glands or other serious ailments.

Germany, which for the past fifteen years has carried out a very thorough system of medical inspection for the school children of the Empire, was first to make this new departure, in educational method, or rather this return to the original type. London followed the example of Germany, beginning, last year, with one open-air school as an experiment, increasing the number this year to three. In Germany the schools are 
kept open until Christmas; in London they closed about the first of November. The object is to cure as well as to teach. In the Montpelier House School, Kentish Town, N., we found a group of children working under almost ideal conditions from the hygienic standpoint. A long shed, open on the whole of one side and 'not too close' on the other three was the schoolroom. Here the children worked in rainy weather, and at other times when the work was such as to necessitate tables. Otherwise the class sessions were beld out of doors in the open or under the trees. 'The little camp chairs which served as beds later in the day did service now for "recitation benches," and had the advantage of being easily moved from place to place or disposed in groups as occasion demanded. The school hours are from 9 A. M. until 7 P. M., which seems a long day for "invalid children" unless we keep in mind that three meals are served during that time (in Germany four), and that after the noon meal every child must "sleep" for two hours. Naturally some pairs of wide-awake eyes refuse to shut just because the clock declares that now is the proper time; but at any rate each individual must keep quiet in his own particular corner and let the others sleep. If the weather is fair and the ground not too damp, thick blankets like 'steamer rugs' are laid four folds thick upon the ground and here the children take their after-dinner nap. If the ground is water-soaked or the weather too damp, the camp chairs serve for couches and the rugs are wrapped about the children. In the afternoon emphasis is placed upon gardening and other mantual work. After the evening meal the children return to their homes. According to the report of the London County Council, a head mistress, three assistants, a nurse, cook, cook's assistant and a 'schoolkeeper' are allowed to each school of 70 pupils. The school physician also keeps a strict watch and careful records of the physical condition of each individual child from week to week.

With respect to the effect upon the children of this out-door life we may best quote from the report of Dr. Frederick Rose, of Eng., who placed on exhibition in the Educational Department of the Franco-British Exhibition a model of a set of buildings designed for an ideal Open-air School. His remarks apply especially to the German experiment, but judging from the statements of the teachers, they are equally true of the London schools. Dr. Rose says :

"The work of the school doctor consists in keeping a careful watch on the bodily condition of the children. He weighs them, constantly examines the heart and lungs, the state of the blood, and general condition with regard to color, muscular and flesh development. Plenty of mineral, slipper, and sun baths are given.

The first physical results after the first experiment, which was carried out four years ago with a hundred children for three months, 
were very remarkable. Twenty-three per cent. were cured, forty-five greatly improved. The second experiment, which lasted five months, gave still higher percentages of cures and improvements. Nearly half of the anæmic cases were cured and about a third of the scrofulous cases. More than half of the consumptive cases showed great improvement, and cases of heart trouble were appreciably diminished. The increase in weight per child was about six or seven pounds, or roughly about half a pound per week, per child. Many children increased by eight pounds, and eleven children showed an increase of from eleven to eighteen pounds. The children's bodies also became bardened, to some extent, by their constant sojourn in the open air, so that even during wet and cold weather they scarcely ever suffered from colds and similar indispositions.". . . "The educatiopal results were no less remarkable. All the teachers noticed the increase of mental attention and alertness. Three months after the children returned to the ordinary town schools, reports were sent in from the head masters showing that in all cases they were able to resume and continue their work in a normal manner. In a few cases their progress was even more satisfactory than before their attendance at the open-air school. These educational results were brought about by small classes of twenty-five children to one teacher, by a reduction of the hours of formal instruction, and generally by bringing the instruction into touch with out-door conditions, and thus stimulating the children's interest. These are very significant results, and raise the question as to whether the instruction in elementary schools could not be imparted in a different manner with greater benefit to the children's health and a better utilization of the large sums expended on elementary children. If such results can be obtained with debilitated children taken out into the open, their hours of instruction reduced, the number of teachers increased, and their health looked after, what results could we not hope to attain with normal children under similar conditions?"

"The behavior, too, of the children showed great improvennent, especially with regard to order, cleanliness, self-help, punctuality, good temper and kindly disposition. This was attributed to their isolation from street life, to the constant intercourse with the teachers outside the formal hours of instruction, and to their sharing in the daily tasks required of a community."

Mr. Rose suggests further that open-air schools can be built at a reduction of at least one-third of the expenditure required in constructing an ordinary schoolhouse, also that portable buildings might be so constructed that they can be takeu apart and thus transferred from place to place as is already done in other cities. "The great success of the portable Doecker school buildings on the Continent and in some parts of England has shown that this can be done, even for a school of six hundred children, as often as necessary, quickly, cheaply and with great ease. At Berin, for example, there is a portable 'Doecker' school of no less than twenty-two class-rooms and a gymnasium."

Incidentally such schoolhouses as these might be made to contribute to the solution of another problem which confronts American cities, namely, the shifting of the population from one part of the city to another, due, frequently, to the opening 
up of some new industry, or transfer of an old one, the restult of which is that schoolhouses built to accommodate the population as it was at the time of building, become partially emptied, while in other parts of the city the congestion is so great that all the pupils cannot be accommodated.

Swimming Schools. Swimming schools are not unknown among us but their importance in America is extremely insignificant compared with the same type in London. It may be argued that in a country where so large a proportion of the population is living inland, there is not the same necessity or value in teaching swimming as in England, and this is true. Nevertheless we veuture to suggest that knowledge of swimming is quite as likely to be of practical value as knowledge of baseball, or football playing, while, leaving utility aside, the sport from the mere standpoint of organized games seems to have a value of its own quite sufficient to make it equal if not superior in rank to the two games just mentioned. Moreover, while it has the desirable qualities of team work and competition which the other two games have, it is freer from their objectionable features. Certainly one could hardly devise a cleaner sport and, as the committee of the Swimming Association suggests, the swimming school may be one solution of the playground problem in congested districts where land is scarce and very difficult to obtain for school purposes. The Preliminary Report of the National Education Association, I908, p. $2 I$, says of backward children, many of whom come from the slum districts:

"One of the most astonisbing phases of this work [of specialclasses
of truants and incorrigibies] is that these boys, although they live
their lives on the street, are unable to do regular physical exercises
and know nothing of the games and plays of the normal boy of hap-
pier homes. They are awk ward, unwieldly, and heavy-footed, with
the shuffing gait and hanging head which mark the loafer and crimi-
nal as well as the mental defective, and the simplest physical tasks
are beyond their strength. In a few weeks' time the change in this
direction is very great. Careful drills in marching, in steps, in pos-
ture, and exercises calculated to remedy individual defects, form part
of the scheme of work. Teams for basket-ball, baseball, running, etc.,
have been organized and the boys have learned to do creditable team
work. Here again we found an unexpected ethical good resulting
from something begun for other purposes. The team spirit . . ;
has led to pride. . . this personalpride. . . [to] self-respect."

The London Swimming Schools are arranged in "centres" so placed as to be in reach of the greatest possible number of day schools. By this arrangement I, I4I schools have the benefit of the swimming school baths. IO0,000 children receive instruction in swimming. Life-saving has a very prominent place in the courses of instruction given. At stated times "a Swimming Gala" is beld when various schools and swim- 
mers contend for champiouship. Last year the contest began to take on an international type when a French team come over to play against the London children.

The following is a condensation of the long and interesting programme which was presented on the evening of our visit. The spectators' seats were crowded to their fullest capacity, the cheering on all sides enthusiastic. Except in the case of the 'fancy and scientific' swimming and number 23 of the programme, all the combatants were children under fifteen years of age.

I. Lady-Learners' Race-Across Bath and Back. Ist Prize, Silver-backed Hair-Brush. 2nd " Fountain Pen.

2. Junior Championship (males), Two Lengths.

3. Orie Length, Ladies. Ist Prize, Silver Cruet. and " Butter Dish. 3rd "Silver Ritig Stand.

4. Senior Cham pionship (males), Three Lengths. Ist Prize, Gold Medal. and " Gold Links.

5. Ladies Championship. Two Lengths. Prize, Gold Medal.

6. Final Ore Length, Ladies.

7. Final Senior Championslip (males), Three Lengths.

8. Junior Team Race (males). Ist Prize, 3 Sets Gold Fronted Links. and " 3 Pocket Knives.

9. Exhibition of Fancy and Scientific Swimming.

ro. Ladies' Team Race. Ist Prize, 3 Gold Centre Medals. and " 3 Bottles of Perfume.

II. Senior Team Race (maies). rst Prize, 4 Sets Gold Fronted Studs. and " 4 Walking Sticks.

12. Ladies, Diving. Ist Prize, 3 Gold Plated Hat Pins. and " 2 Silver Plated Hat Pins.

13. Final Junior Championship (males).

14. Final Senior Team Race (males).

I5. Final Ladies Team Race.

16. Grand Display of High, Scientific and Acrobatic Diving.

17. Breast Stroke Championship (nales), Two Lengths.

18. Pinal Junior Teatn Race (nales).

19. Life Saviug. Ist Prize, 2 Clocks. 2nd " 2 Pairs Gold Fronted Links.

20. Back Race (males). rst Prize, Clock. and " Case of Electro-plated Salt Cellars.

21. Diving (males). Ist Prize, Gold Links. and " Gold Plated Fountain Pen.

22. Final Life Saving (males).

23. Lady Waterlily's Tea Party.

24. Final Back Race.

25. Final Breast Stroke. 
Number 23 was a variation from the serious work of the evening, being an English tea served in the middle of the bath the guests being conveyed thither in large flat-bottomed tubs, and refreshments brought on trays placed on the top of tubs. The difficulties of keeping balance while sailing in stich a craft, of looking "swell" when dumped out into the water, of serving tea on sucb a rickety table, of posing gracefully in water deep enough to just take one off his feet, together with other incongruities of time and place, furnished the fun of the occasion.

While commending most beartily the work and spirit of the Swimming Association as a whole, we may perhaps be permitted to enter a protest agaiust such long programmes, three hours or thereabouts, considering the age of the contestants, also against the custom of offering all sorts of incongruous prizes, where the activity and pleasure of the work itself should be its own reward. To divert the attention from the legitimate purposes of the training, such as physical development and good natured rivalry and the power it gives in saving life to the far less worthy aim of winning a butter dish or a cane, seems indeed a pity. Nor is this a custom resiricted to the swimming schools alone. The prize system in this objectionable form, now, happily, almost obsolete with us, seems to be still a thoroughly established feature of the English school in all its types. On my table is an invitation to visit a day school on "Prize Day" when "three hundred medals and prizes" were to be distributed "for Regularity. Punctuality, General Progress and Good Conduct!" A system of class instruction which needs such artificial stimulation as this may well be scrutinized with very great suspicion as to the psychology of the methods employed. Furthermore it may be quite possible that the fictitious interest thus aroused may result in mo:e harm than good by taxing the strength of immature and growing children beyond what their tender years can bear. Indeed we are informed that this was the case with the swimming competitors, at least, inasmuch as on the last contest of the year, one boy died as the result of over exertion.

Of the very great practical salue of the training, however, there can be no question. During the past year alone, thirteen lives have been saved by mere children, the oldest fourteen, the youngest eleven years old. In all eighty-five lives have thus been saved, and eighty-five children's names have been inscribed upon the Roll of Honor. What a splendid record! And what a noble incentive to hold before a child's ambition! Who would wish to obscure this potential, genuine reward, by placing between it and the earnest eyes fixed upon it; a cane or butter-dish! 
Three or four cases taken from the Report of the Swimming Association for 1907 will serve to show how soon the real reward may come to any child contestant.

"Thomas Knight, aged 12, of Rotherfield Street School, Islington, rescued Jobu Poole on May 16th, 1907, in the Regent's Canal, New North Road. Four boys were playing on the towing path, when Knight, who was fishing, heard the cry of 'That boy is drowning.' He took off his coat and waistcoat, and jumped in, but was immediately clutched round the neck, and astruggle ensued. Kujght, however had been taught 'Release drill' at school, and soon freed himself. He placed his hands on the other boy's face, and soon swam on his back to the bank. Here lie was assisted by companions, and after a while Poole was taken home; and put to ber.

"Awarded Royal Humane Society Testimonial on Vellum."

"Henry Titlow, aged I2, of Moreland Street School, saved the life of Arthur Cooper, 8 years old, on May 24th, 1907. Cooper was fishing from a log of wood chained to the bank of the Regent's Canal, when he fell into the water about seven feet deep, and was sinking for the third time when Titlow, hearing cries for help, climbed over the wall, ran about 40 yards, and pulled off his coat and vest. He dived into the water, swam to the midale of the Canal and brought the boy to the side where he was helped out by two men. This action of Titlow's was all the more meritorious because he himself had only just recovered from rheumatic fever, and was even then suffering from St. Vitus' Dance for which he was atteuding University College Hospital. He had learned to swim the previous year.

"Awarded R. H. S. Testimonial on Vellum."

"Alexander Smith, aged r2, of Smeed Road School, Old Ford, saved the lives of two boys, William Hughes, aged Iu and John Biggs, aged 4 , on two separate days, viz., 6 th and 7 th of July, 1907, both on Duckett's Canal, Old Ford. Smith had only obtained his First Class Certificate the previous year.

"Awarded R. H. S. Certificate."

"Charles Harvey, I3 years old, also of Ilderton Road School, rescued Alice Tennison, aged Io, on August 4 th, 1907, in the Grand Surrey Canal, Old Kent Road. The girl, who attends a Mentally Defective Centre, was trying to walk along a narrow coping by the side of the canal, when slue fell in. Harvey was 250 yards away when bis attention was called, but he ran to the spot, and divesting himself of his jacket and waistcoat only, be jumped in. The Canal is deep at the place, and the girl was almost unconscious, nearly in the middle of the Canal. The parents of the girl rewarded Harvey with sixpence. [twelve cents.]

"Awarded R. H. S. Testimonial on Vellum."

Sittlement Schools. One other kind of educational work remains to be mentioned, namely the Settlement School. We include this with the others described not because the work differs very much from that of our own "Settlements" but because the mauner of organization of some, at least, may have practical suggestions for us. The Fern Street School Settlement, Devons Road, Bromley-by-Bow, E. happens to be the one concerning which we have fullest accounts. We glean the following facts from data kindly furnished by Miss Clara Grant, the organizer of the school. 
In a district where social conditions have impelled the wellto-do-people to more away, where economic stress is so severe that one woman declared "We have to kill ourselves to keep ourselves," and another, "All the outing I ever gets is out of the washtub and back again;' where, it is said, 4.046 babies under one year of age have died in the past five years;' where "purisy", "indigestion on the lungs," "St. Viper's dance" and other strange diseases run riot; where one mother describes her little girl as having "'ooping cough, pumonia, and bronchitis, and as Dr. R. said, 'you could n't wish 'er to 'ave more" here the "School Settlement" is trying to solve the difficult problem of how to exist. The day scbool is taken as the 'base of operations,' standing as it does in vital relation to every home having in it a child of school age. It is still a County Council School in the sense that it receives financial aia from the county treasury, but to the ordinary day school the usual features of "Settlement Work" have been added. It is to this feature of the Fern Street Settlement, which seemingly, might be utilized by those interested in Settlement Work, "Organized Charities" and by School Boards-this working in co-operation with the day school in the alleviation of suffering, rather than apart from it-that we wish to call attention.

Tu those who have never viewed Settlement life from the inside, a little further account of its activities may not be uninteresting. Among the projects which Fern Street Settlement is either already carrying out or proposes for the immediate future are the following:

Regular visiting of children's homes; breakfasts for children who cannot have proper food at home; records kept at the Settlement of each home, its needs, deficiencies, difficulties; mothers' social gatherings (at the Settlement), where there shall be "a little talk, a little tea, and a little music," meetings for fathers; a lending library for parents; lectures on Infant Care; a day nursery, where working mothers can leave their children as they go ont to work and where, at the same time, working girls can be trained as 'children's nurses'; assistance in finding work for the unemp'oyed; a medical club by means of which mothers, in lieu of a small weekly payment. may receive medical assistance for themselves and children without further pas; encouragement to, and personal watch over, girls going out to service; helping children to 'outings' in the country; distribution of old clothes for the very needy; provision of toys for the children; providing Christmas trees; interesting other children in sending toys to the Settlement, etc.

The Settlement permits no indiscriminate giving and no giving of any sort without some, though often small, return. Mothers who are too poor to buy even old clothes for their 
children are permitted to pay in labor, which is utilized in making over other clothes at the Settlement or in manufacturing toys for the children out of old toys or other material donated to the Settlement. It was found, however, that some of the mothers did uot know how to cut material to be renovated, so a class was organized to teach them how.

A visiting nurse makes a part of the staff of the Settlement workers. Twice daily minor ailments such as sore eyes, throats, etc., are treated by the resident nurse. The more serious cases are cared for at home, and here we may add that in some sections in England a nurse's wages are paid out of public money, and any one within a certain limit is free to call upon her for private services-another suggestion for both the organized charities and for the Board of Health. What better assistance could be given to the congested districts of our large cities where the death rate is so alarmingly high? What better way of educating the people into hygienic living, while, on the other hand, the resident nurse might be a most efficient ally in carrying out the instructions of the Health Officers.

The English Educational System. We have already referred to the Education Act of 1902 , indicating that very many of the recent innovations in Educational affairs have taken place since that time. Pausing now to take a hasty survey of the forces which are thus shaping the Educational Policy we find two, which seem to claim leadership-Parliament and the National Union of Teachers.

County Council Schools. Parliamentary action expresses itself at present in the County Council Schools, which since I902 have superseded the Board Schools established in 1870 . "Local Authority,"' vested in County Councils are now responsible for the maintenance, control, and supervision of all elementary education, even of church and private schools so far as subjects taught, and quality of teaching is concerned. In the large cities this arrangement applies under very large limitations, to secondary and higher education also, that is to say, the County Councils co-operate with institutions already established. The action of County Councils must be approved, however, by the Board of Education, 'which is the central authority intrusted by Parliament with the duty of supervising all branches of education throughout the country.'

It will thus be seen that the recent tendencies in Educational Policy are toward decentralization of power and distribution of responsibility. In its practical working this act of 1902 seems to have given a great impulse to the evolution of a consistent and efficient system of Education. On the administrative side "the Act of $\mathrm{I} 9 \mathrm{O} 2$ has co-ordinated elementary and higher education, improved and developed the training of 
teachers, and raised the standard of efficiency in both elemeutary and secondary schools," while on the theoretical side, the opportunity is furnished for re-discussion of the whole field of method of presentation of subject matter, adaptation to age of pupils and locality, content of curriculuin, etc. These discussions fiud forceful expression through the medium of the National Union of Teachers, of which we shall next speak.

The "N. U. T." The National Union of Teachers is a democratic organization in which each member of the Union, whether present or not at the Annual Conference, casts a vote for the officers. The association "is neither an incorporated Professional Institute nor a Trade Union, but it combines the best features of each, with certain functions peculiarly its own. It was in the first instance a 'Union' of several Associations of Teachers which had been organized on denominational lines; it is now a Union of [495] Local Associations." It includes teachers of elementary, secondary and higher schools, excluding no one "on occount of creed, party, or class of school."

This society seems to us superior to any educational organization existing in the United States, not only in its thorough organization, but in its scope; in its efficiency of action; and in its direct and indirect benefits to the members of the Union and to the cause of education in general. As many of its features may well be studied with a view to partial or complete incorporation into our own educational organizations, we state below the objects of the Union, as formulated in its official publications :

I. "To associate and unite the teachers of the kingdom of England and Wales."

II. "To provide means for the co-operation of teachers and the expression of their collective opinion upon matters affecting the interests of education and the profession."

III. "To improve the condition of education in the country, and to obtain the establishment of a national system of education, cu-ordinated and complete; also to secure for all Public Elementary Schools adequate funacial aid from public sources, accompanied by suitable conditions."

IV. "To afford to the Board of Education, the Local Authorities for Education, and other organizations-public or private-which have relation to educational affairs, the advice aud experience of the associated teachers."

$v$. "To secure the effective representation of educatioual interests in Parliament."

VI. "To secure the compilation of a comprehessive register of teachers, and to promote and extend the influence and dignity of the profession of teaching. To secure the recognition of the Union as a Diploma-granting Authority."

VII. "To watch the administration and working of the various Acts, Codes, Minutes, and Directories; to endeavor to amend their terms and administrations when educationally desirable; and to endeavor to secure the removal of difficulties, abuses, and obsolete regulations detrimental to progress." 
VIIr. “'To raise the qualifications and status of teachers and to open to the best equipped members of the profession the higher posts in the educational service of the country, including the Inspectorate of Schools."

IX. "To promote the welfare of the Teachers' Provident Society and the Teachers' Benevolent and Orphan Fund."

$X$. "To watch the alministration of the Superannuation Act and the Pension Minutes, and to endeavor to secure their amendment."

$X I$. "To afford advice and assistance to individual members in educational and professional matters and in legal cases of a professional nature."

XII. "To extend protection to teachers wrongfully dismissed."

Among the reforms which the Union claims to have accomplished are Education Acts and Amendments to Education Acts and Factory Acts; the extension and liberalization of curricula; the abolition of rigid atd unnatural classifications of scholars by mere age; the reduction of over-pressure on yonnger pupils ; the establishment of more hygienic conditions of study in school; improvement in the enforcement of school attendance; extension in the school life of children; reductions of the "Half Time" system ; the abolition of universal annual examinations of schools; the abolition of the examination of each scholar; better adaptation of studies; improvements in methods of inspection and examination and teaching; extension of facilities for the training of teachers; revision of regulations for day and evening schools; election of educational experts on governing bodies for education. It acts as a medium of communication between teachers and Parliamentary and other governing bodies; gives professional counsel, legal advice and social companionship to its nembers; affords members help at law if prosecuted, libelled, or otherwise defamed. "It has established a Provident Society enabling its members to obtain at lowest rates, annuities and sick and death payments, to accumulate savings, and to purchase their bouses." "It bas established a Benevolent and Orphan's Fund which maintains two orphanages. It grants temporary relief and annuities to infirm teachers, and widows of teachers, and renders other beneficent help."

"By repeated claims, by representations to the Education Department and to Members of Parliament, and by resolutions in the House of Commons, it has secured the establishment of a general scheme of superannuation for certificated teachers."

"Each year the principal regulations issued by the Bnard of Education are brought together and are published with explanatory notes incorporating all the latest official and legal decisions bearing on educational work."

"The National Union of Teachers sends representatives to outside meetings of other associations having an educa tional or sociological bearing, including International Conferences, and 
receives such representatives from other countries, thus enabling the members to compare national educational ideals. It aids visitors from other countries who wish to visit English Schools."

The Union "has secured the retention of the right of reasonable corporal punishment by head teachers, and the recovery of the same prerogative for certificated assistants in many localities"'; the reduction in the ratio of pupil teachers to adults; the right of appeal against disastrous reports by inspectors, and against the suspension or cancellation of diplomas; freedom from secret reports and log-book entries by inspectors and principals. Reports adverse to teacher must now in many schools be shown to the teacher before presentation to the local authority and the teacher must be allowed to present his or her side of the case at the same time that the adverse criticism is made. In many cases salaries have been increased and lowering of salaries prevented.

2.432 members of the Union received advice on educational matters last year. Legal advice is also given free. r 70 legal cases were dealt with last year by the Education Committee. Legal assistance covered claims for damages and salary, cases of corporal punishment, assaults on teachers, illegal dismissal, libels, etc.

Among the results for which the "N. U. T." is still working, are the extension of secondary education, especially for rural pupils; equality of salaries for class mistresses and class masters working in mixed or boy's departments; less irksome conditions of service; more freedom in selecting subject matter taught; earlier promotion of efficient teachers, 'a uniform scale of salaries'; reduction in size of classes; retention of girl's schools for women teachers; prevention of combined departments "which close the door to promotion for women."

The Union claims to be the greatest and most influential organization of teachers in the world, and asserts that nearly all the improved conditions of school life are due to its efforts. Certainly much has been done even if wuch still remains to do. Can we point to a similar organization on this side the water which has accomplished as much? To be sure we may not agree that all the ends accomplished in the N. U. T. would be desirable in America, but that is merely a matter of detail in adjusting to home conditions. In our own Teachers' Associations, whose work is largely limited to the discussion of purely professional subjects, we seem to have come nearly to a s'andstill with nothing more profitable to do, unfortunately, than to thresh out the same old straw which was brought to the pedagogical mill a decade or two ago. Would it not be an exhilarating variation from eloquent platitudes respecting the nobility 
of the teaching profession, and endless discussions on comparative merits of classical and scientific studies, to really do something. Suppose the teachers should prove the nobility of their profession by bringing all their united influeice to bear upon stich problems as the banishment of "graft" from the adoption of text-books, the building of schoolhouses, and the election and dismissal of teachers; upon the securing of medical inspection in schools; of separate rooms for backward children; Iibraries for country schools; suitable playgrounds; rest rooms for sick children or teachers; smaller classes; adjustabie seats and desks for growing pupils; evening schools for those whom the day school does not reach; trade schools; representation of women on school boards; Parents' schools where Genetic Psychology should be studied, and methods of teaching explained, to the end that parents might co-operate in Educational Reforms, not work against them as is so often the case now.

Suppose the whole teaching body should demand, and back up the demand with legal procedure, public meetings or whatever means are necessary to accomplish the purpose, that the eyes of the children no longer suffer througin the use of shiny desks, and glazed paper in text-books; that the selection of text-books be in the hands of experts, not left to some ignorant member of a school board who never taught a child, and whose sole criterion of choice in books is the amount of commission offered. Or let them demand that equal salaries be paid to men and women for equal work, thereby checking the present tendency to drive men out of the teaching profession by placing cheap labor on the market; that malicious libels and uujust dismissals on the part of principals and superintendents or other teachers, be punished by forfeiture of position and disqualification to hold any educational office or position thereafter; that indemnity be paid to those who have thus suffered. The writer could name a school in which, within two years' time, nearly every member of a Faculty of twelve or fifteen teachers, ove after another, was either summarily dismissed or forced to resign. It is true the principal lost his own position during the second year, but this did not in any degree undo the harm which he had wrought bis teachers.

Do we say "It is of no use, we could not bring about these reforms?" Our English cousins are showing us that it is of use, that teachers if united can bring about reforms in educational methods and administration, and that, too, in the face of inertia and opposition which is absolutely unknown to us. It seems a little incongruous, perbaps, that England should teach America Democracy, but the criticism which the English teachers who visited the United States, make upon our 
School System-that it is "undemocratic" - is undoubtedly just. Teachers have no choice either in the selection of their colahorers, or of the men under whom they are to serve.

These are some of the sadly needed reforms which touch most closely, perhaps, the daily life of teacher and pupil, but these are not all. Considering the educational system of the United States in the broader international bearing of its great power, as $\mathrm{Mr}$. Mosely suggests, in determining what rank the United States shall attain among other nations,-from this point of view, also, the deficiencies of our School System become painfully apparent. With England, France and Germany, where changes are made by the Central Government, any advance means practically advance along the whole line. With us it may be purely local. Accustomed to $\mathrm{fx}$ attention upon the most progressive states or cities, we lose sight of those that are lagging behind.

We need, then, first of all

(I). More spurring up by public sentiment of the laggards in the race, which when it has accomplished its purpose will give more solidarity to the educational work, and more opportunity for co-operation in efforts to improve existing conditions.

(2). Local Teachers' Associations having for their object the bringiug about of specific local reforms in Education, these organized again into State Associations with power to influence Legislation in favor of Educational needs.

(3). Inclusion within the reach of Educational Instruction of every individual within the boundaries of the United States, implying, of course, curricula broad enough and flexible enough to fit some, at least, of the needs of every individual person, extending thus the limits of the "school age" so as to cover the entire life.

(4). More careful husbanding of the "waste products of society" - a study of the causes which have produced these products, and removal and prevention of the causes. This should be done, not only in order to transform the "social waste" to "social wealth", but in order that the knowledge thus gained may be utilized for the better training of the whole body. To carry out this work, many more schools for defective clildren and adults will be necessary, free medical inspection, free hospitals where children may be treated, trained nurses to see that instructions are carried out, more industrial schools, trade schools, more evening schools, far better training for teachers than at present, especially for teachers of backward children; extension of Settlement Work to all the slum districts, swimming schools to help 'clean up' the slums and supplement the playgrounds. 
(5). All instruction FREE.

Is the question raised as to where the money is coming from for all this vast expenditure? The answer is "From the funds now wasted in Graft." Only a few days ago the writer was told that in one of our largest cities the school tax per dollar is more than twice the amount of the actual cost of the schools. And yet the city is short of funds to carry on its educational work!

Conclusion. Such, briefly, are the lessons and suggestions which the Twentieth Century Crusade yielded to one member of the Five Hundred. Standing amidst the monuments of England's glory and of her shame, we could not but look forward to a time when two thousand years of our own history shall be epitomized in painting, sculpture, and wax, and could but wonder if it, too, shall have its "Chamber of Horrors," to humble the pride of future generations! We must admit that there is much of truth in the charges which England brings against us, of political corruption, of infidelity to public trust, of superficiality, and other lesser faults adhering to our younger, cruder, and in many respects sadly defective institutions. Only by acknowledging these defects are we likely to overcome them and only by the study of more perfect models are we likely to be fully conscious of their presence. Just here comes in the value of a Dynamic Pedagogy which, keeping fast hold of those elements which are desirable and even essential to the best development of American life, shall yet reach out on every side for suggestion and inspiration with respect to those features in which other nations are our acknowledged superiors. To establish such an international exchange of ideas in education, using the word in its broad sense, is only to extend the policy which we have long since recognized to be the true one in the building up of industries and institutions. To us who were fortunate enough to share the generous opportunity given during the past year, for just such interchange of thought, it seemed as if we had little in comparison to offer to those coming to the United States for similar study. And yet, reverting to the report of Mr. Mosely, we dare to hope that even in America there is something good and at the same time truly American. Thrown into contrast with English characteristics and conditions, perhaps the home possessions which seemed most precious as we turned toward them once more were the following:

(I). Individual initiative, which, so far as our observation extended, is largely lacking in English schools.

(2). Free secondary as well as free elementary schools.

(3). A fluidity of social conditions which acknowledges no fixed barriers of cast or class. 
(4). Power of quick adjustment to changing conditions.

(5). Faith in the ability and integrity of the masses.

These, we venture to think, are qualities with which we should not willingly part, and qualities which our school system will do well to foster. How to keep this vital content while perfecting the form; how to combine the vigor and individuality of our young life with the richness and mellowness of age-this is our problem. If such characteristics of American life as those above named commend themselves to the study of our friends across the sea; if it be true that, intent upon the capture of educational spoils, both their and our invading armies have profited by this campaign carried out in the interests of Primary and Secondary Education, then, would that we might dare to hope for some self-sacrificing knight to extend the field of operations, and to lead a Second Crusade recruited from College and University ranks. 